the difference exceeded $4^{\circ} \mathrm{F}$. Also, over large areas the precipitation changed from 75 per cent of normal to 125 per cent. Significant changes in the general circulation, lasting about six years, are thus clearly shown.

\section{REFERENCES}

(1) World Weather Records, Smithsonian Mise. Collection, vol. 79 (whole number), 1927.
(2) Bir Gibert Walker, Correlation in seasonal variations of weather, Indian Met'l Memoirs, 24, pt. 4, 1923.

(3) T. A. Blair, Summer and autumn pressure anomalies affecting winter temperatures in the upper Mississippi Valley, Mo. Wea. Rev., 58, 1930; 53-58.

(4) T. A. Blair, Relations between winter temperature and precipitation, Mo. Wea. Rev. 59:34-35.

(5) W. J. Humphreys, Physics of the air, 2d ed., 1929; p. 595.

\title{
STORM WARNINGS ON THE GREAT LAKES
}

By George A. Marr, Vice President, Lake Carriers' Association

[Presented before the American Meteorologieal Society, Cleveland, Obio, December 20-30, 1930]

Surrounded in our homes, in our offices and plants, and in every phase of our daily lives, as we are to-day, by a multiplicity of conveniences and utilities, we are prone to accept these aids and comforts as matters of course and look upon them with blase indifference. We see them and use them with no interest beyond the comfort or convenience of the moment. The railroad, the motor car, the telegraph, the telephone, the radio, the moving picture, the iceless refrigerator, are merely things that are. Who stops to ponder over the research, experiment, study, labor, and organization that brought them into being or to develop them from primitive into complex and efficient instrumentalities of pleasure, usefulness, education, and better living?

This thought came home with striking force when I received the invitation to present a paper to your learned society on the subject of "Storm Warnings on the Great Lakes." I was aware that we have storm warnings, that they are indispensable to the safety of navigation, that the mariners place great dependence upon them and that we break into characteristic sailor vernacular if there is suggestion of their discontinuance before the last boat of the season is in winter quarters. And yet they have a history of development which has been obliterated from our consciousness by the long period during which the Government has performed for us this invaluable service. We have enjoyed the benefits of this service so long that we have looked upon it as complacently as you have upon the running water in your bathrooms, without thought of the engineer who designed and constructed the pumping station or the engineer who operates the pumps.

Failure of your automobile or your telephone brings dismay and harsh criticism. I can recall no instance of failure of the Weather Bureau to give advance warning of any serious storm, but it is conceivable that the results of any such failure might entail incalculable loss of life and property, and the importance of the service to safe navigation has always been regarded with the highest esteem. The Weather Bureau is entitled to the highest eneomiums. No estimates can be made of the number of lives saved nor the millions of dollars worth of property preserved to transportation by their timely warnings of storms. It is no uncommon occurrence for dozens of vessels to remain in a harbor of safety in consequence of these advance notices from the Weather Bureau and I would be neglectful indeed if I failed to acknowledge, in this opportunity, the debt of gratitude which the sailor, the vessel owner, the shipper, and the traveling public owe to the faithful, devoted, and scientific service rendered by the officials and men engaged in this humanitarian calling.

The Weather Bureau was established by act of Congress in 1890 superseding a similar service inaugurated 20 years before by the War Department under a joint resolution of Congress becoming effective July 1, 1871.
Under this joint resolution of Congress, the Secretary of War was charged with the duties of taking meteorological observations and giving notice on the seacoasts and on the northern lakes by "magnetic telegraph and marine signals of the approach and force of storms." The Secretary of War was also authorized to establish signal stations at lighthouses and at such of the lifesaving stations on the Lakes or seacoast as were suitably located for the purpose. Lake commerce has therefore enjoyed for 60 years a storm-warning service under the direction of either the War Department or the present organization in the Department of Agriculture.

When this service was inaugurated in 1871 the commercial traffic of the Lakes as measured by the statistics of commerce at the locks of St. Marys Falls had barely outgrown its swaddling clothes. The first lock at the Soo witnessed in its opening year, 1855, a freight traffic of less than 15,000 tons. This had grown in 1871 to nearly 600,000 tons carried in 573 steamer and 1,064 sailing ship cargoes. The commerce of the St. Marys Falls Canals now reaches a total of $100,000,000$ tons in approximately 19,000 vessel passages, and the aggregate volume of the freight movement on the Great Lakes is around $150,000,000$ tons carried annually in the navigation period of about seven and one-half months.

The adoption of the joint resolution of Congress establishing the storm-warning service was concurrent with the launching of the first bulk freighter on the Great Lakes. The steamer Robt. J. Hackett, the forerunner of the present type of ore, coal, and grain carriers, was launched in 1870 . She was then the "leviathan" of the Lakes, of wooden construction, 211 feet in length and carried about 1,000 tons at the depth of water then prevailing in the connecting channels. While the type of vessel thus established has remained unchanged, the structural material has changed from wood to iron and then to steel, and the size of ships has grown to a length of 600 feet and over, with a carrying capacity sixteenfold that of the Hackett. It may also be interesting to note that at the time the storm-warning service was inaugurated, sailing vessels constituted the major portion of the Great Lakes fleet. To-day there is not a sailing vessel left in the commercial trade of the upper lakes, the last one, Our Son, having foundered in the September storm of the past season. Incidentally this ship was built five years after the inauguration of the storm-forecasting service. Such has been the transformation of the lake fleet in 60 years. To a person not familiar with the Great Lakes the question may occur as to whether on these inland waters storms could arise of such force as to be of serious consequence to the large steel vessels of the present day. In this connection it is only necessary to refer to the storm of 1913 in which nine modern steel steamers were sunk without trace, and one, a 10,000-ton vessel loaded with coal, floated, bottom side up, on Lake Huron for several days, a striking manifestation of the power of a lake storm. 
That the storm-warning gervice was undertaken by the Government primarily for the benefit of navigation is evident from the provision of the joint resolution of 1870 which authorized the establishment of marine signal stations, and also from the act of 1891 in which the duties, of the Weather Bureau are enumerated in the following order:

(a) Forecasting the weather.

(b) Issuance of storm warnings.

(c) Display of signals for the benefit of agriculture, commerce, and navigation.

Then follows the enumeration of a half-dozen other duties, but that the giving of warnings to commerce and navigation was the prime purpose of the Government is apparent from precedence given to these services in the language of the act.

It will be noticed that the joint resolution establishing the service under the direction of the Secretary of War required the Secretary to give warning of the approach and force of storms by "magnetic telegraph and marine signals." Since that time there have been remarkable advancements made in means of communication. The "magnetic telegraph" itself has undergone great development, not only by invention and improvement, but by expansion, so that communication by this means is now universal and the wire facilities for making forecasts and broadeasts have been greatly improved. But at best the "magnetic telegraph" affords means of communication only with land stations and with ships that are either in port or passing so closely to port as to be able to see the visual signals of impending storm. Vessels that have passed these sources of information before warnings were issued are at the mercy of the storm until reaching the next shelter, perhaps hundreds of miles distant, after the breaking of the storm.

The most marked, the most important, and I might say, the most dramatic step in the evolution of facilities for communication lies in the invention of the wireless telegraph. Neither the Weather Bureau nor the navigation interests have been slow to recognize the benefits of this and apply them to the paramount purpose of saving life and property at sea. There is rarely a violent storm at sea that does not bring to us through the press stories of ships in distress that have been succored and saved by other vessels which have received through the ether the magic S O S signal. While we of the Great Lakes can not "point with pride" to instances of this character that occur so frequently on salt water, we have nevertheless equipped many of our vessels with radiotelegraph instruments, not only to maintain busiuess contact with the ships' officers but to enable them to receive timely warning of atmospheric disturbances and to seek whatever shelter their location and the force and direction of the storm may dictate.

The means of communicating warnings to the vessels at the present time are-

(1) The display of flag and lantern signals at land stations.

(2) The radiotelegraph broadcast.

(3) Broadcasts from radiotelephone broadcasting stations.

The distribution of storm information by the display of flags by day and lanterns by night is the primitive means of conveying the intelligence to ships' masters, and yet, in spite of the progress made by radio, these flag and lantern signals stand to-day as necessary to the safety of navigation as when they were inaugurated 60 years ago, and any thought of their discontinuance must be abandoned, or at least deferred indefinitely.
There are 115 such stations on the Great Lakes, 82 of which are maintained by our Government and 33 by the Dominion of Canada. These are located at strategic points in the various harbors or at conspicuous places on the banks of the connecting rivers, where vessel officers about to leave shelter may, seeing the warning, come to anchor until danger is past.

The ships of United States and of Canadian registry receive the benefit of the warnings displayed by either country. There are in the commercial trade of the Great Lakes 875 vessels, 581 of which fly the Stars and Stripes and 294 the British jack.

The act of June 24, 1910, amended by the act of July 23,1912 , makes it unlawful for any steamer of the United States or of a foreign country navigating the ocean or Great Lakes and licensed to carry or carrying 50 or more persons, including crew, to leave a port of the United States without radio apparatus of 100 miles radius, excepting as to vessels plying between ports not in exeess of 200 miles apart.

Under the provisions of this act none of the lake freight vessels is required to be equipped and only a fow of the passenger ships. The lake vessels, however, have been equipped to the extent of 224 out of the 581 Amerioan vessels and 84 of the 294 ships of Canadian registry, leaving between five and six hundred vessels that are not equipped to receive advices by wireless telegraph.

For communicating storm warnings to these radiotelegraph equipped vessels broadcasts are sent out at stated hours daily over the entire Great Lakes area. These broadcasts are sent in code from wireless telegraph stations at Duluth, Great Lakes, Chicago, Mackinac Island, Rogers City, Alpena, Cleveland, and Buffala, giving information as to both prevailing and expected weather conditions, and warnings of storms whenever indicated.

In addition to this, a number of ships equipped with direction finders and a larger but unknown number on which officers or members of the crews have installed private "unofficial" receiving sets for entertainment are able to receive the radiophone broadcasts sent out daily. by some 30 broadcasting stations at practically every hour of the day.

Such rapid development has followed in the wake of the invention of radio that the most fanciful dreamer can not envision the progress that is still to be made, and there is a disposition to look forward to the perfection of the radiotelephone, already in probationary service, before assuning the cost of equipping the remaining ships with the existing devices, with the current expense of operation and the probability of early abandonment for the substitution of improved equipment.

A deeply appreciated and highly commended additional service was established last year (1929) in an arrangament made through the Weather Bureau office at Duluth and the R. C. A. radiotelegraph station in that port. Under this arrangement reports are sent to Duluth from vessels on the open lake giving details of weather conditions prevailing in the vicinity of these vessels. This information is transmitted ta vessels in port at Duluth and Superior, where weather conditions are often of marked difference in character from those prevalent the lake. Not infrequently masters, warned of severa weather on Lake Superior and of which there was no indication in port, remained in sehlter until reporting vessels gave indication of moderation. So gratefully was this information received by masters that a simflar arrangement was made during the season just closed to 
inform masters at Sault Ste. Marie of the weather conditions on the east end of Lake Superior and the north end of Lake Huron.

As previously stated, the lake ships have been equipped far beyond the requirements of law, but the major portion of the commercial fleets of both United States and Canada is still dependent upon the flag and Iantern displays. In addition to these unequipped vessels of the larger classes engaged in interlake trade there are numerous small eraft, such as fishing vessels and yachts to which the flag and lantern displays are the only available warnings of threatened storm.

I have no hesitancy, therefore, in stating that no thought should be given at the present time to the withdrawal or material contraction of the primitive system of flag and lantern displays. On the contrary, if this service can be expanded to greater usofulness in the saving of life and property the study of the Weather Bureau should be directed to that end. For instance, these signals show merely that a storm may be expected from a certain point of the compass. If a simple revision of the code could be arranged to show the anticipated force of the expected storm, the additional information would be valuable.
I make the further suggestion that the Weather Bureau might render an added service by the forecasting of fluctuations in the lake levels, particularly in the vicinity of the shoal places governing the loading depths of the vessels. Some vears ago Mr. Frank Jermin, the meteorologist of the Weather Bureau at Alpena, Mich., made an extensive study of the effects of barometric pressure on the lake levels and the currents created by the transit of the high and low pressure areas from one part of a lake to another. The merits of Mr. Jermin's deductions I am not competent to discuss intelligently with you gentlemen, but I have a distinct recollection that Mr. Jermin said that these water-level fluctuations could be forecast with reasonable accuracy about six hours in advance of their occurrence. If this be true, may I not recommend to my Weather Bureau friends that consideration be given to the issuance of advance information with reference to these fluctuations?

While the poet sings of the "bounding billows" and the "wet sheet and flowing sea," the marimer reads with much greater concern the indications of his barometer and the reports and warning signals of the Weather Bureau. The stories they tell may not be ever new, but the interest holds longer than it does in other Twice-Told Tales.

\section{SIGNIFICANCE OF AIR AND SEA TEMPERATURES OBTAINED ON CRUISE VII OF THE "CARNEGIE" 1}

By Kathatinf B. Clakk

On the tenth of May, 1928, the nonmagnetic ship, Carnegie, sponsored by the Department of Terrestrial Magnetism of the Carnegie Institution of Washington, took departure from Newport News on its seventh cruise. It was possible on this cruise to inaugurate a complete meteorological program. From the middle of May, 1928, to the middle of November, 1929, except for days in port, air pressure, temperature and humidity, and sea temperature were recorded continuously and a definite effort was made to obtain as accurate records as possible. These Carnegie observations are particularly valuable because in some regions of the Pacific where the Carnegie cruised meteorological data of known accuracy are scanty if not altogether lacking.

Of the meteorological results which are now being compiled at the Department of Terrestrial Magnetism, those of sea and air temperature are the most complete and accurate.

A continuous record of sea-water temperatures at a depth of approximately two meters was obtained with a mercury-in-steel bulb-and-capillary type of sea-water thermograph with daily movement. Sheets were changed daily at Greenwich mean noon. Immediately before each change of sheet the temperature of the surface sea water was measured by the bucket method. This consisted in lowering a canvas bucket into the sea about two feet below the surface, quickly hauling this to the deck and measuring the water temperature by immersing a standardized thermometer in the bucket. The temperature so obtained was entered on the thermogram. In areas where the sea-surface temperature was changing rapidly, as in entering port or in calm weather, a mean of soveral bucket readings was taken.

The thermograms were scaled at every full hour local mean time. The differences between thermograph and bucket readings have been recorded, and these values,

\footnotetext{
1 Based on a paper presented before the American Metøorological Society, Wsshingtoา, May 4, 1931. Also cf. Brooks, Charles F. Meteorological Program of the Seventh cruise of the Carnegie, 1928-1929, MontelY WrateER REvIEw, May, 1929, vol, 67, pp. 194-196. 66i $1 \mathrm{~S}-31-2$
}

used as a correction factor, applied to the hourly thermograph readings to obtain true sea-surface temperatures. Bucket temperatures were higher than thermograph temperatures by $0.8 \mathrm{C}$. to $0.9 \mathrm{C}$. at lower sea temperatures and by $0.2 \mathrm{C}$. to $0.1 \mathrm{C}$. at higher sea temperatures. Comparing temperatures so obtained with the sea-surface temperatures measured at the oceanographic stations with standardized reversing thermometers a difference greater than $0.5 \mathrm{C}$. never was found and at over half the stations the difference was less than $0: 1 \mathrm{C}$. Values of corrected sea-surface temperatures range from $6.4 \mathrm{C},\left(43^{\circ} .5 \mathrm{~F}.\right)$, recorded just south of the Aleutian Islands at $12^{\mathrm{h}}$ July 8,1929 , to $30^{\circ} 2 \mathrm{C}$. $\left(86^{\circ}: 4 \mathrm{~F}\right.$.) approaching Pago Pago at $14^{\mathrm{h}}$, November $14,1929$.

For obtaining air temperatures several types of apparatus were used. The Hartmann and Braun electricresistance multithermograph was installed for the purpose of obtaining lapse rates from deck to masthead. Three pairs of wet and dry bulb thermometers were installed at various heights above sea level-one pair in the Stevenson shelter on deck 12 feet (3.6 meters) above sea level, another pair in a ventilated screen just above the crosstrees on the mainmast 72 feet (21.9 meters) above sea level, and a third pair at the masthead on the mainmast 113 feet (34.6 meters) above sea level. These Thermometers were calibrated from time to time with an Assmann aspiration psychrometer.

The usefulness of these Hartmann and Braun records has been lessened because corrections for all the single thermometers can not be obtained. It is evident that the recorded values depend upon the efficiency of ventilation of the screens, which in turn is modified by direction and velocity of the wind. Unfortunately these windrecords were lost in the destruction of the vessel.

An examination of these Hartmann and Braun records has revealed a diurnal variation in the apparent lapse rates between deck and crosstrees (masthead-records were too incomplete for use). This must be due to heating of the deck-thermometer during the daylight hours. 